\title{
ADOPTION OF CONSERVATION AGRICULTURE AND ANALOG FORESTRY IN BUI DIVISION, NORTHWEST REGION, CAMEROON
}

\author{
TSI Evaristus Angwafo ${ }^{1} \boldsymbol{凶}$, Kemkia Christian Danernyuy ${ }^{2 \square}$
}

${ }^{1}$ Department of Fundamental Science, Higher Technical Teacher Training College (HTTTC) P.O. Box 39 Bambili, The University of Bamenda

${ }^{2}$ Department of Rural Sociology, Faculty of Agronomy and Agricultural Sciences (FASA) P. O. Box 222 Dschang, University of Dschang

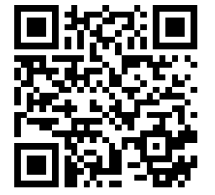

\section{DOI: https://doi.org/10.29121/IJOEST.v4.i3.2020.83}

Article Type: Research Article

Article Citation: TSI Evaristus Angwafo, and Kemkia Christian Danernyuy. (2020). ADOPTION OF CONSERVATION AGRICULTURE AND ANALOG FORESTRY IN BUI DIVISION, NORTHWEST REGION, CAMEROON. International Journal of Engineering Science

Technologies, 4(3), 35-58. https://doi.org/10.29121/IJOEST.v 4.i3.2020.83

Received Date: 04 May 2020

Accepted Date: 14 June 2020

Keywords:

Adoption

Conservation Agriculture

Analog Forestry

\section{ABSTRACT}

Analogue forestry involves blending traditional knowledge and science to recover and valorise indigenous knowledge, creating systems that are familiar to traditional societies and meet the needs of contemporary forest-dependent communities. Conservation agriculture is based the principles of minimal soil disturbance, permanent soil cover and crop rotations so as to achieve sustainable and profitable agriculture and improve farmers 'livelihoods. Every farmer is a researcher, who experiments every season on his or her farm. Farmers who find something that works are likely to repeat it the next season, and to tell their friends about it. This study set out to examined the extent of the adoption of conservation agriculture (CA) and analog forestry (AF) in Bui, the sociocultural and economic benefits of these agricultural methodologies to the population. Feld observations, interviews and the administration of questionnaires was the methodology used. The data were analysed descriptively and by simple statistical techniques using SPSS. The findings posits that CA and AF have been greatly adopted thanks to the farmers, government and NGOs/CIGS in Bui Division. The adoption of these strategies have contributed at improving the socio-cultural, economic and environmental conditions of the people. Finally, the study concludes that there has been $81 \%$ adoption of CA and $61 \%$ adoption of AF which has significantly benefited the population through increase in source of income, environmental protection and drop in cost of production.

\section{INTRODUCTION}

Agriculture accounts for an estimated 22.5\% of the Gross Domestic Product (GDP) of Cameroon, 27\% of export earnings and $15 \%$ of fiscal earnings. It employs nearly $70 \%$ of the workforce. Arable land is estimated at 7,000,000ha. There are 1.2 million farms, $70 \%$ of which have an area below 2 ha. The country's agriculture is rich and varied, but largely underutilised. The main cash crops are cocoa, coffee, cotton, oil palm, rubber, bananas and pineapples. The major food crops are tubers (cassava, macabo, cocoyam, yam, Irish potato and sweet potato), plantain, cereals (rice, maize, sorghum and millet) and vegetables (beans, cowpeas, groundnuts and soya). Agriculture, apart from plantations, is generally extensive, based on subsistence with the surpluses sold in the markets to purchase other needs (Appraisal Report, 2003).

(C) 2020 The Author(s). This is an open access article distributed under the terms of the Creative Commons Attribution License, which permits unrestricted use, distribution, and reproduction in any medium, provided the original author and source are credited. 
Conservation agriculture was born out of the United States' dust bowl of the 1930s (Hobbs et al., 2008) and is widely practised in large-scale commercial agriculture in North America, Brazil, Australia, Argentina, Morocco, South Africa and Paraguay, and increasingly in Europe, China and India. The current focus of research is on the adoption of conservation agriculture to the needs of smallholder farmers in Africa, Asia and South America who lack the resources, particularly mechanisation, of large-scale commercial farmers. Conservation agriculture is based on three principles: minimal soil disturbance, permanent soil cover and crop rotations and its aim is to achieve sustainable and profitable agriculture which will improve farmers' livelihoods (FAO, 2006). The practice of conservation agriculture holds potential for all farm sizes and varied ecological conditions, and it is seen as particularly useful for smallholder farmers, especially those with labour and input shortages in the drier tropics (Sebastian et al., 2004).

Conservation agriculture emerged in several different places around the same time in Africa. The most dramatic story comes from Zimbabwe and Zambia, where conservation agriculture came to the rescue of the land. It is now being introduced in Cameroon through the Conservation Agriculture Project for Mount Cameroon by the Limbe Botanic Garden with German government sponsorship through GATE-GTZ.The most important researchers and promoters of conservation agriculture in Africa are farmers themselves. Every farmer is a researcher, who experiments every season on his or her farm. Farmers who find something that works are likely to repeat it the next season, and to tell their friends about it (Wirsiy, 2010).

On the other hand, is a particular method of agro forestry that was originally developed in Sri Lanka i.e analog forestry. It restores the productivity of degraded land and provides new sources of food and income to local people. In essence, an analogue forest imitates the original native forest and has similar (analogous) structures and ecological functions. Analogue forestry adds certain crops and trees which provide food and marketable products such as pepper, cinnamon, mangoes and other spices and fruits. Tea and coffee also grow well in the shadow of the trees. Analogue forestry involves blending traditional knowledge and science. It recovers and valorises indigenous knowledge, creating systems that are familiar to traditional societies and meet the needs of contemporary forestdependent communities (Dufty, 1998).The practice is still very recent in Cameroon and is being promoted by and organization called Centre for Nursery Development and Eru Propagation (CENDEP).

With the recent improvements in the agricultural sector over the last four decades a combination of declining soil fertility, population growth, low uptake of external inputs, and climate disruption has resulted in a dramatic fall in per capita food production (Pretty et al 2011). In addition, the new agricultural technologies are hardly successful in Sub-Saharan Africa, where hunger is on the increase. Important pockets of poverty remain in areas characterized by rain fed agriculture or fragile soils and which affects close to one billion people a phenomenon belief to be caused by the adoption of technological innovations that are not sustainable (Melesse 2018). This therefore calls for the neccesity to advocate the adoption of innivatins that are sustainable.

Innovation adoption appears to be lagging in the country with the countries peasant farmers depending more on the adoption of old farming techniques that go a long way to keep contributing to environmental degration and continous drop in the their farm yields.According to Melesse (2018), a series of factors contribute to this amongst which include the fact that when the household head or leader is a aged person, families are liable to rely on the adoption of old farming techniques. Also, the educational background of the population of the community greatly contribute in influencing the types of innovations adopted in the communities. The main objective of this study therefore was to investigate the conservation agriculture and analog forestry techniques adopted in Bui Division in the North West Region of Cameroon. Specifically, the study helped to determine the socio-cultural, economic and environmental potentials of conservation agriculture and analog forestry. The study hypothesised that CA and AF practices have been significantly adopted in Bui Division.

CA and AF have significantly improved the economic and socio-cultural lives of the people of Bui.

\section{METHODOLOGY}

\subsection{THE DESCRIPTION OFTHE STUDY AREA}

\subsubsection{LOCATION}

Bui Division is situated between latitudes 6o00" to 6o20" North of the Equator and longitudes 10o30" to 10o60" East of the Greenwich Meridian (Figure 1). It is a huge orographic plateau within the Cameroon Volcanic Line (CVL)

$\underline{\text { International Journal of Engineering Science Technologies }}$ 
with spectacular mountainous landscape like Mount Oku (3,011m above sea level) and the Mbaw-Tikar Plains (about $900 \mathrm{~m}$ above sea level) (Tume, 2008). It provides a major watershed for the Niger and Sanaga river systems. The Division has a total surface area of 2,795 km2 (Divisional Delegation of Lands, Bui, Kumbo), with Kumbo as its headquarters. It has six Sub Divisions namely: Kumbo Central (630 km2), Jakiri (675 km2), Nkum (375.3 km2), NkorNoni (307.7 km2), Mbiame (575 km2) and Elark-Oku (232 km2). Bui Division is bordered to the North by Donga and Mantung Division, to the North East by Boyo, East by Mentchum, South East by Ngoketunja, and finally in the South West by the Noun Division which is in the Western Region.

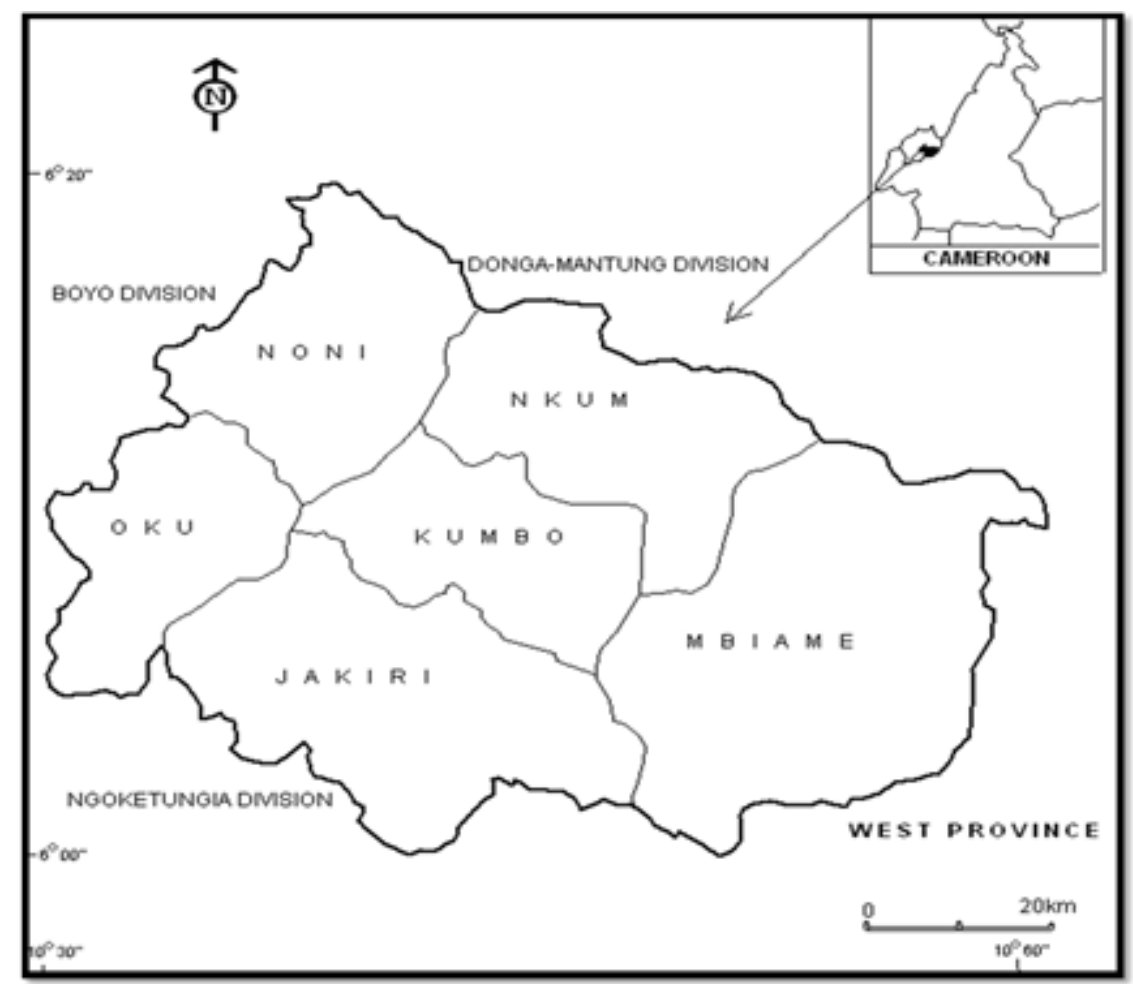

Figure 1: The map of Cameroon showing the location of Bui Division and her villages Source: Realized from the Administrative Map of Cameroon, N.G.C., Yaounde, 1994

\subsubsection{DATA COLLECTION}

Qualitative descriptive design was used assessing the adoption of conservation agriculture and analog forestry while quantitative design was used in assesing the economic and socio-cultural significance of conservation agriculture and agrofrestry. The sampling procedure was purposive since the population is made up of those carrying out agriculture especially conservation agriculture and agrofrestry. From each category simple random sampling technique was applied to select the respondents.

The sample size was obtained using a percentage of the population from each sub-divisional headquarter. Therefore, 180 questionnaires were distributed to respondents as shown on table 1 below

Table 1: Distribution of questionnaire per sub-division in Bui

\begin{tabular}{|l|c|c|c|}
\hline Sub- division & 2015 census projections & Percentage proportion (\%) & Questionnaires \\
\hline Kumbo central & 330862 & 52 & 94 \\
\hline Mbven & 28984 & 4 & 8 \\
\hline Noni & 30008 & 4 & 8 \\
\hline Jakiri & 118216 & 18 & 33 \\
\hline Oku & 131892 & 20 & 37 \\
\hline Total & 632,428 & 98 & 180 \\
\hline
\end{tabular}


Data were analyzed descriptively and inferentially using statistical package for social sciences, cross tabulation and MS Excel.

\section{RESULTS AND DISCUSSION}

Appraisal of Conservation agriculture and agroforestry in Bui division (figure 1).

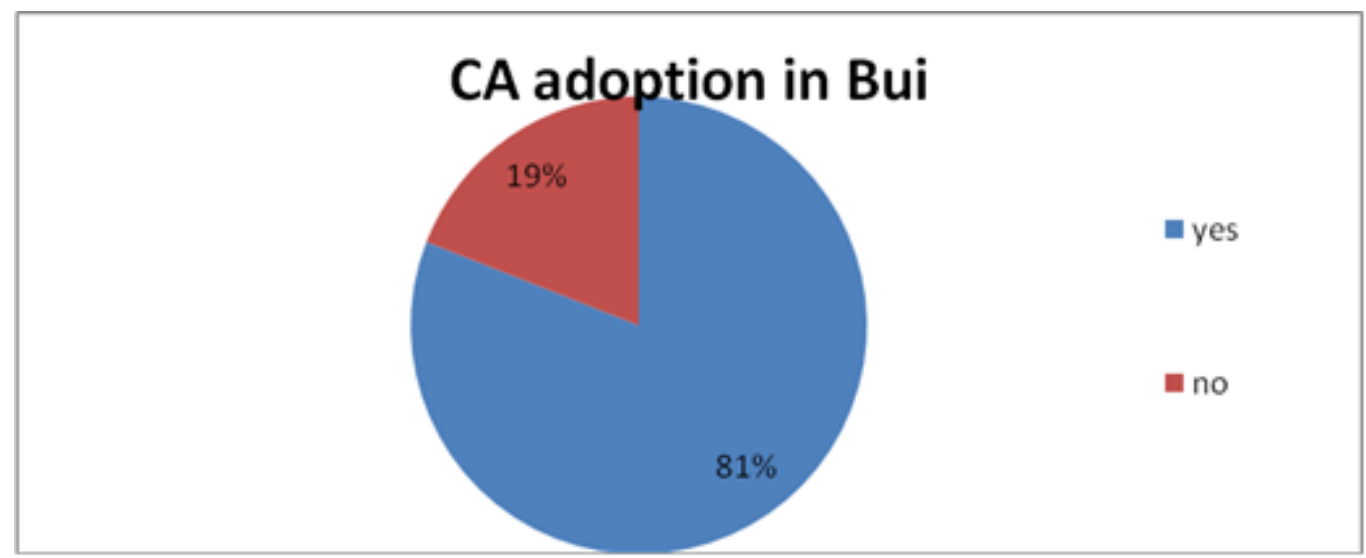

Figure 1: Conservation agriculture adoption in Bui division

$80 \%$ of the population has adopted this practice with common characteristics on their fams like minimal soil disturbance, permanent vegetation cover, direct sowing (no raking) and crop rotation. This farming practice in Bui is referred to as "Beneficial Farming" which yields profit overtime because they say Workchop! No suffer ground! No Nag Skin! This farming techniques are used by many when farming cassava, maize, cocoyam, beans sweet potatoes and soya beans in the montane areas and lowlands of the division. This farming system is practiced on rich volcanic soils, poor soils, forest and grassland, hills and plains, and dry and wetlands.

\subsection{CONSERVATION AGRICULTURE PRACTICE IN BUI DIVISION}

The conservation farming concept developed and promoted in Bui Division is a merger of technologies originally promoted by the farmers and Government. The main practices identified in the study areas are summarized in table

Table 1: Summary of CA technologies in Bui division

\begin{tabular}{|l|l|l|}
\hline Practice & Key elements & Principle \\
\hline $\begin{array}{l}\text { No-burning, } \\
\text { slashing and } \\
\text { mulching }\end{array}$ & $\begin{array}{l}\text {-Slashing of vegetation } \\
\text {-Biomass left to serve as mulch } \\
\text {-No burning or partial burning is done if biomass is too much } \\
\text { and will disturb planting and germination } \\
\text {-Planting directly with dibbler }\end{array}$ & $\begin{array}{l}\text {-Soil cover } \\
\text { disturbance }\end{array}$ \\
\hline $\begin{array}{l}\text { Minimum tillage and } \\
\text { direct planting }\end{array}$ & $\begin{array}{l}\text {-Land preparation done by slashing vegetation with little tillage } \\
\text {-Spray herbicide (glyphosate) after weed regrowth of about } \\
\text { 30cm height } \\
\text {-Direct planting of maize, beans, soya beans or plantain through } \\
\text { the mulch } \\
\text { without burning }\end{array}$ & -Minimum soil \\
disturbance
\end{tabular}




\begin{tabular}{|l|l|l|}
\hline $\begin{array}{l}\text { Crop } \\
\text { rotation and } \\
\text { intercropping } \\
\text { with legumes }\end{array}$ & $\begin{array}{l}\text {-Intercropping or relay-intercropping of leguminous cover } \\
\text { crops (e.g. beans, soya beans, groundnuts) }\end{array}$ & $\begin{array}{l}\text {-Permanent soil } \\
\text { cover, }\end{array}$ \\
& $\begin{array}{l}\text { - Harvest of main crop, cover crop left on the field as short fallow } \\
\text { - Cover crop biomass protected from bush fires and excessive } \\
\text { grazing } \\
\text { - Direct planting without burning }\end{array}$ & $\begin{array}{l}\text { disturbance and } \\
\text { crop rotation }\end{array}$ \\
\hline $\begin{array}{l}\text { Cover crop } \\
\text { sweet potatoes) } \\
\text { Herbicide }\end{array}$ & $\begin{array}{l}\text {-Cover crop established as a sole crop } \\
\text { - Hebicide used to kill the biomass } \\
\text { - Maize, vegetables, cassava or plantain planted directly }\end{array}$ & $\begin{array}{l}\text { Permanent } \\
\text { cover and minimum } \\
\text { soil disturbance }\end{array}$ \\
\hline
\end{tabular}

\subsection{NO-BURNING, SLASHING AND MULCHING}

Under a system of no burning but slashing and mulching, farmers slash the vegetation with a cutlass or machete to prepare the land and in cases where the area is too grown, partial burning is done to reduce disturbance from residue during planting and germination. The biomass or vegetation is left to dry to form mulch. Maize is planted directly through the mulch, which has not been burned. Planting is done manually using a planting stick or a cutlass.

Weed control is done manually using a cutlass or machete, or with a hand-held hoe. Fertilizer may be applied if cash is available. Pests and diseases are addressed through integrated pest management, using chemicals only if deemed necessary. This conservation agriculture technique is used for all types of crops, but in Bui (18.3\%) of the farmers (table .2), used predominantly on maize, beans and soya beans. Within the season, farmers benefit from soil water conservation and weed control through the presence of the mulch. In addition, the physical and biological properties of the soil are expected to improve after the mulch decomposes.

Table 2: Percentage adoption of conservation agriculture technologies in Bui

\begin{tabular}{|l|c|c|}
\hline Conservation agriculture technologies & Respondents & Percentage \\
\hline little-burning, slashing and mulching & 33 & 18.3 \\
\hline Alley cropping with cover crops & 29 & 16.1 \\
\hline Minimum tillage and direct planting & 53 & 29,4 \\
\hline Crop rotation and intercropping & 40 & 22.2 \\
\hline Cover crop (sweet potatoes) and Herbicide & 13 & 7.2 \\
\hline Total & 168 & 93.3 \\
\hline missing data & 12 & 6.7 \\
\hline Total & 180 & 100,0 \\
\hline
\end{tabular}

Three main strategies are used to facilitate this technique; they are; ploughing, tractor tilling and spaying.

\subsection{PLOUGHING}

ploughing, disking or soil cultivation to prevent loss of soil organic matter and nutrients, actually is the order of the day for the conservative farmers of Bui Division and from the interviews carried out, more than $29 \%$ of the farmers practice this strategy; crop and cover crop residues stay on the surface, there is direct seeding or planting with little or no disturbance of the soil; permanent crop and weed residue mulch protects the soil are should neither be removed nor burnt. These processes definitely result to a build-up of soil organic matter and reduced nutrient loss. Also, in this process, lime and sometimes fertilizers are surface-applied where necessary.

However, fertilizer usage is minimal in any CA. Attaining the above therefore calls for proper sensitisation and the use of specialised equipment for seeding, fertilizer and herbicide application and mulch management (figure 2). 


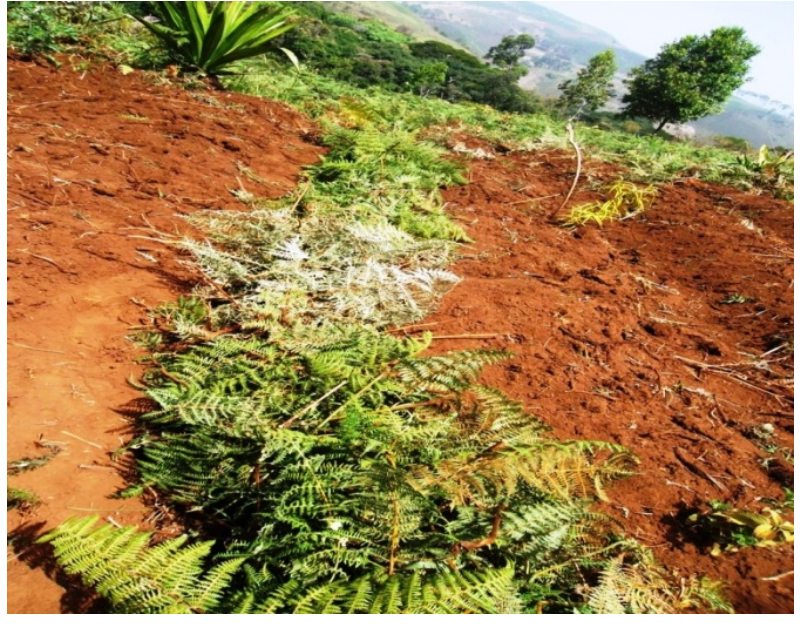

a

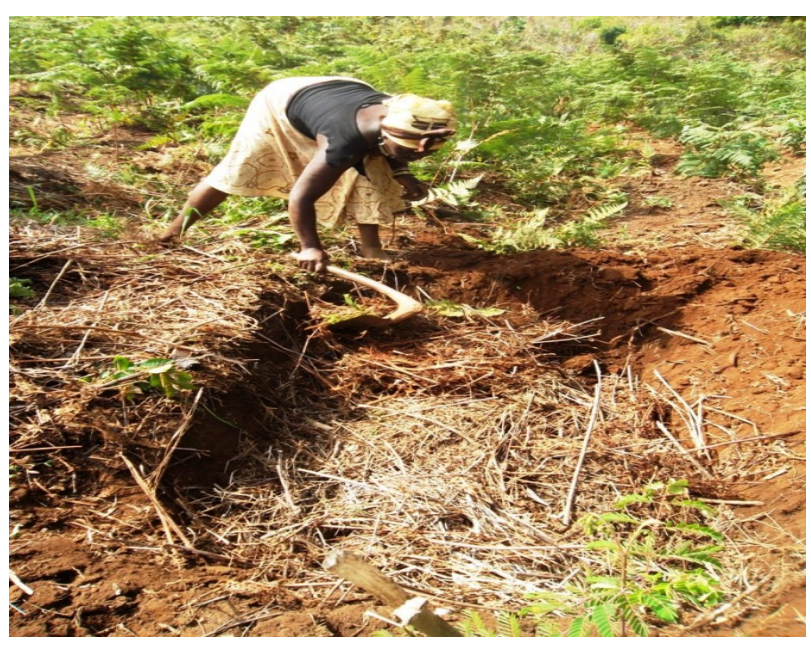

b

Figure 2: (a) The Bracken fern used as a barrier for slope stabilisation and soil erosion control and (b) Vegetation used for the production of mulch used for moisture retention.

\subsection{TRACTOR TILLING}

This is the least used of all the techniques for the preparation of land in Bui division. The technique involves the use of tractors to prepare land. Bui Division as earlier mentioned, has three topographic units, namely, high plateau (above 2,000m above sea level), low plateau (1,500 - 1,800m above sea level) and plains (900-1,500m above sea level) (Tume 2008). The first two do not support the use of tractors because tractors cannot move on slopes thus making it only favorable in the plains that cover the extensive alluvial platform Mbaw-Nso plain, part of Tikar plains which extends to Mbokam and Ber in Jakiri Sub Division. theMbokam-Ber plain gradually falls into the Ndop plain separated by the Wainamah escarpment. There is also another extensive plain north-west of Bui Division (NkorLassin) which is the south-east end of the Donga plain.

Land is prepared using tractors that have a chisel plough that carry minimum tillage mixing the grass with the soil in the process of tilling. Others use tractor modifiedknap sack meant to cover wider swathes for increased operator efficiency. However, few people are able to do this because they rent these tractors and many cannot afford due to the high price (table 3 ).

Table 3: Pricelist for renting a tractor in Mbaw Nso

\begin{tabular}{|l|c|c|}
\hline Area & Unite cost & Final cost \\
\hline 1 hectare & 50000 & 50000 \\
\hline 5 hectares & 40000 & 200000 \\
\hline 10 hectares & 30000 & 300000 \\
\hline Above 10 hectares & 25000 & \\
\hline
\end{tabular}

Source: Mbaw Nso maize cooperative (2016)

\subsection{SPRAYING AND PLANTING}

This technique unlike other techniques is recent in Bui division but appears to be among the highest means of land preparations adopted by farmers in this area.it makes use of the sprayer. The knapsack sprayer ("pump" as locally called) that is usually 15 litters is the most common is the most common tool used by smallholder farmers for applying herbicide. Application requires knowledge and the correct calibration and use of sprayer (table 5.4). During spraying, operator are always advised to walk at a steady speed with constant spray height and constant pressure and spray facing the opposite direction of the wind to avoid inhaling the herbicides. 
TSI Evaristus Angwafo, and Kemkia Christian Danernyuy

Table 4: quantity of herbicide used/ knapsack sprayer

\begin{tabular}{|l|l|}
\hline Quantity of herbicide & Water quantity \\
\hline$\bullet 450 \mathrm{ml}$ & 15 litres water for perennial weeds \\
\hline $300 \mathrm{ml}$ & 15 litres water for annual weeds \\
\hline$\bullet 15$-litre knapsack hectare of land & for $100 \mathrm{~m} 2$ or 8 knapsacks per \\
\hline
\end{tabular}

Source: divisional delegation MINADER for Bui (2016)

Herbicides are of two different types; that is the pre-emergence and post emergence herbicides: Pre-emergence herbicides: Pre-emergent herbicides act upon weed seeds in the soil or form a barrier in the soil to prevent weed seed germination or establishment. A properly timed application can provide control for several months.

Post-emergence herbicides: Post-emergent herbicides work on actively growing weeds and are further broken down into selective or non-selective categories.

- Selective herbicides can be applied to control either broadleaf or grasses. When herbicides for broadleaf weeds are applied, they will little effect on the grass weeds. Some products may require repeated applications for effective control.

- Non-selective herbicides kill all living plant material they come in contact with. Extra care must always be taken when handling non-selective herbicides to prevent spillage or accidents. In Bui Division, the common herbicide use is the post emergence and the most popular non-selective herbicide is Round-Up (Glyphosate) and selective herbicide is herb extra.

To avoid soil disturbance, they spray the weed just before planting, and keep slashing them throughout the season whenever necessary (figure 3a below). The strategy is to reduce and maintain the weed population at the lowest possible level (threshold) thereby making crop-weed competition minimal for the crop to attain its yield potential.

After harvesting they main crop allow the cover crop to establish itself well so as to provide soil cover and smother any emerging weeds. It is also important to manage weeds continuously in the coming season by using appropriate weed control measures depending on the one preferred (figure $3 \mathrm{~b}$ ).

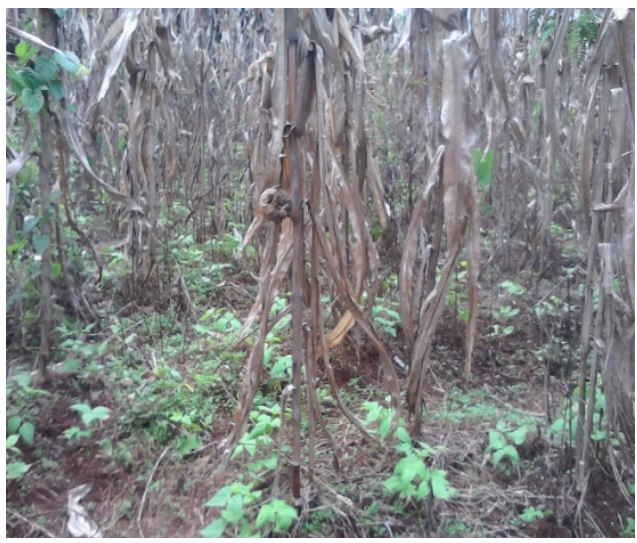

a

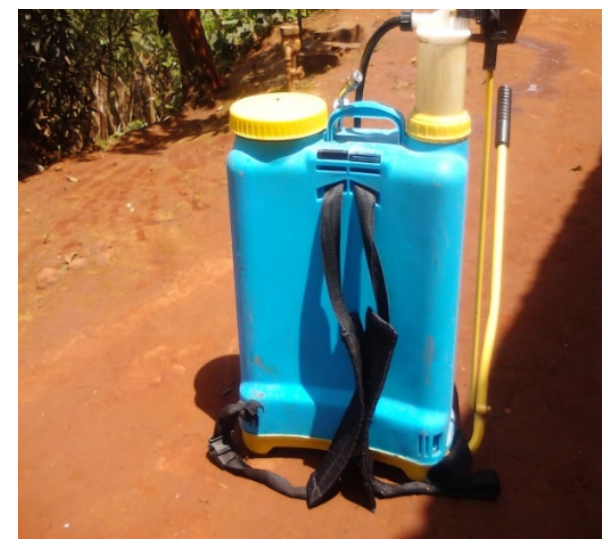

$\mathrm{b}$

Figure 4: a) farm spread with round up and crop planted directly; b) knapsack sprayer used by farmers

\subsection{ALLEY CROPPING WITH COVER CROPS}

Alleys are established using fast-growing shrubs like cassava and coffee or tree species such as fruit trees (orange, avocado, guavas) and natural trees like croton, prunus and Fick tree. Some natural shrubs like tephrosia, quatamela are used for hedges in farms and most of the farmers, also use eucalyptus and cypress for fencing for commercial purposes (figure 5a).

This technique is still under experimentation. Farmers practising it mostly own or have long-term access to the land. Besides maize, cassava and cocoyam have been planted under this system and is very common in Nkwa Nso in Jakiri sub division commonly called "garri land" in Bui. Farmers benefit from the increase in soil fertility that is introduced through the foliage from the trees cover crops. Soil water is also conserved and weeds are controll. 


\subsection{COVER CROPPING}

Cover cropping, is also another CA technique used to prepare land in Bui division. $22 \%$ of the farmers affirm that this technique is effective and that it involves the use of crops like sweet potatoes, pumpkins and beans. These crops are preferred to others because they grows quickly providing ground cover to protect the soil from direct sunlight and prevent erosion, produces heavy leaf biomass, aggressive enough to compete with weeds and has multiple uses such as being suitable for human food and as animal feed, has multiple uses e.g., edible seed for humans, animal feed, fixes Nitrogen in the soil (figure $4 \mathrm{~b}$ ).

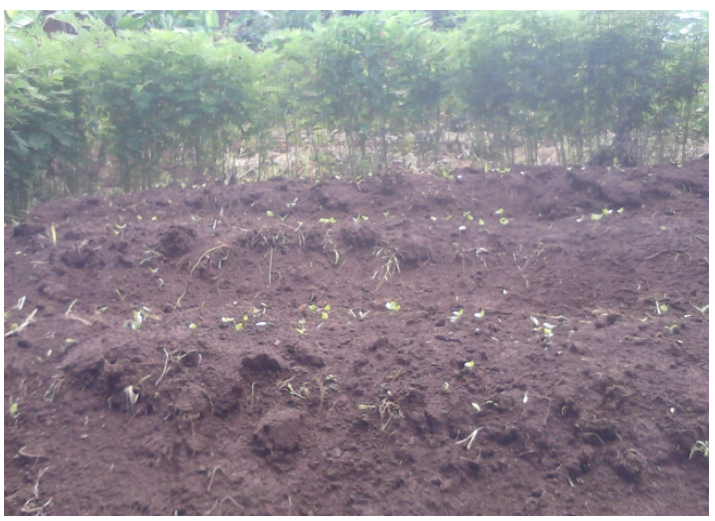

a

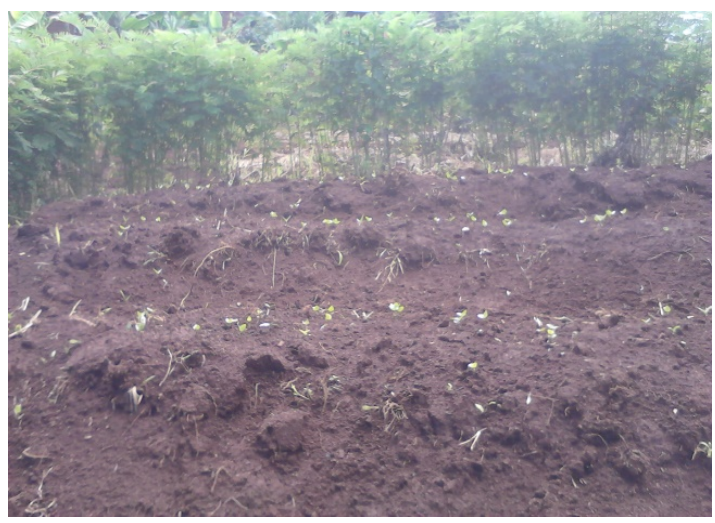

$\mathrm{b}$

Figure 4: a) alley cropping with tephrosia b) Use of sweet potatoes as cover crop

"we di ever plant we this sweet potato and pumpkin for we farm them because e di grow fast and na fine chop where we di all Nso man di choppam, and when you plantam e di cover soil and e no di over dry.e di even makam you no di work farm again" (a farmer in Mbaw Nso appreciates their adoption of cover cropping).

This appreciation shows how cover crops have ease the preparation of land in Bui, and as such, one may already say with some degree of certainty that all farmers in Bui adopt cover cropping technique of land preparation.

After sowing the main crop, they plant a cover crop between the rows of the main crop 2-3 weeks after. Regularly check for weeds and control them by pulling out, scraping the soil surface with a hoe, or using selective herbicides. This practice should continue even after harvesting the main crop

\subsection{CROP ROTATION AND INTERCROPPING WITH LEGUMES}

Crop rotation (the cultivation of crops one after another; that is; When after harvesting one crop then the second is planted). This practice in the context of Bui division is in itself unique to the area this is because in most of the farms in Bui division, one will hardly see one crop in the farm; Multiple cropping is adoptedpurposely to ensure that the soil in their farm is covered by a crop or cover-crop or plant residue (table 5 below).

Table 5: crop rotation and intercropping in Bui division

\begin{tabular}{|c|c|c|c|c|c|c|c|c|c|c|c|c|}
\hline $\begin{array}{l}\text { Type } \\
\text { intercrop }\end{array}$ & Jan & Feb & Mar & Apr & May & Jun & Jul & Aug & Sep & Oct & Nov & Dec \\
\hline $\begin{array}{l}\text { Beans- } \\
\text { groundnuts } \\
\text { intercrop }\end{array}$ & \multicolumn{3}{|c|}{ Land preparation } & \multicolumn{2}{|c|}{ Groundnuts planted } & & \multicolumn{2}{|c|}{$\begin{array}{l}\text { Groundnuts } \\
\text { harvested }\end{array}$} & \multicolumn{3}{|c|}{ Beans cultivated } & \\
\hline \multirow[t]{2}{*}{$\begin{array}{l}\text { Maize-beans } \\
\text { intercrop }\end{array}$} & \multicolumn{3}{|c|}{ Land preparation } & $\begin{array}{l}\text { Maiz } \\
\text { with }\end{array}$ & ed mixed & & \multicolumn{2}{|c|}{$\begin{array}{l}\text { Maize } \\
\text { harvested }\end{array}$} & & & & \\
\hline & & & & \multicolumn{3}{|c|}{ beans intercrop } & & & \multicolumn{4}{|c|}{ Beans planted after maize } \\
\hline $\begin{array}{l}\text { Maize-cowpea } \\
\text { intercrop }\end{array}$ & \multicolumn{3}{|c|}{ Land preparation } & \multicolumn{3}{|c|}{ Maize planted } & & \multicolumn{4}{|c|}{\begin{tabular}{|l}
$\begin{array}{l}\text { Cowpea planted after maize } \\
\text { harvest }\end{array}$ \\
hared
\end{tabular}} & \\
\hline $\begin{array}{l}\text { Maize-soya } \\
\text { beans intercrop }\end{array}$ & \multicolumn{3}{|c|}{ Land preparation } & \multicolumn{2}{|c|}{ Maize planted } & & \multicolumn{3}{|c|}{ Maize harvested } & \multicolumn{2}{|c|}{$\begin{array}{l}\text { ption 2: Soya beans } \\
\text { fter maize }\end{array}$} & \\
\hline
\end{tabular}

International Journal of Engineering Science Technologies 
TSI Evaristus Angwafo, and Kemkia Christian Danernyuy

\begin{tabular}{|c|c|c|c|c|c|c|}
\hline & & $\begin{array}{l}\text { ptior } \\
\text { lante }\end{array}$ & $\begin{array}{l}\text { n 1: soya beans } \\
\text { ed intercrop }\end{array}$ & & Soya harvest & $\begin{array}{l}\text { option 3: Soya beans after } \\
\text { maize }\end{array}$ \\
\hline \multirow[t]{2}{*}{$\begin{array}{l}\text { Potatoes-maize- } \\
\text { potatoes }\end{array}$} & $\begin{array}{l}\text { Land } \\
\text { preparation }\end{array}$ & \multicolumn{2}{|c|}{$\begin{array}{l}\text { Potato esplanted } \\
\text { mixed with Maize }\end{array}$} & \multirow[t]{2}{*}{$\begin{array}{l}\text { Potatoes } \\
\text { harvest }\end{array}$} & $\begin{array}{l}\text { Maize } \\
\text { harvested }\end{array}$ & $\begin{array}{ll}\text { Option1: } & \text { Potatoes } \\
\text { planted to be } \\
\text { irrigated }\end{array}$ \\
\hline & $\begin{array}{l}\text { Option } \\
\text { Potaoes planted }\end{array}$ & 2: & $\begin{array}{ll}\text { Maize } & \text { planted } \\
\text { and potatoe } \\
\text { harvested }\end{array}$ & & Maize harvested & \\
\hline \multirow{2}{*}{$\begin{array}{l}\text { Vegetables- } \\
\text { maize- } \\
\text { vegetables }\end{array}$} & \multicolumn{2}{|c|}{ Land preparation } & \begin{tabular}{l|l} 
Maize \\
planted
\end{tabular} & & Maize harvested & Option 2: tomatoes planted \\
\hline & & \multicolumn{4}{|c|}{ Option 2: Vegetables (tomatoes, huckleberry) } & $\begin{array}{l}\text { Vegetable } \\
\text { irrigated }\end{array}$ \\
\hline
\end{tabular}

Source: author (2016)

Rotations:

Groundnuts -beans

Maize-beans intercrop-beansMaize -beans or soya beans

Maize-soya beans intercrop-soya beans

Vegetables (tomatoes)-Maize- vegetables (tomatoes)

Potatoes - maize - potatoes

Maize-potatoes intercrop-potatoes

The common multiple cropping system used is the simultaneous cropping techniques (cultivation of more than one crop in a year) and three of these techniques are used that is; mixed intercropping; ratoon cropping, strip intercropping and sequential cropping.

Mixed intercropping (the process where more than one crop are grown in a broadcast method. Seeds are not sown in lines and different seeds may be sown together but, in most cases, little intervals can be maintain (Hasanuzzaman 2003)). The crops that are mixed in this system immediately after land preparation be it clearing, spraying or cover cropping include pumpkin, beans, sweet potatoes, potatoes, cocoyam and cassava this system, is adopted by all farmers in the community.

The following reasons where advanced to justify why farmers adopt this practice;

- It helps to increase the fertility of our soils

- The many crops give us guarantee that we will always have food

- The crops also prevent soil erosion

Another simultaneous cropping technique used by the population of Bui is ratoon cropping (the cultivation of crops that after harvest, lower parts of the plant develop suckers, little suckers or tillers Hasanuzzaman (2003). Crops adopted for this practice include mostly vegetables like huckleberry, cabbage common in Jakiri and kumbo central sub- divisions; banana and plantains in Noni sub-division. This cropping system with vegetables is common during the dry season especially along river banks. The following reasons where advanced as to why this practice is highly adopted by these areas in the community because;

- Re-plantation is not needed

- Production cost is low

- They are less time consuming

- The crops increase soil fertility

- Some plantains and banana leafs are used as feed for sheep, goats and cattle in the dry season

- provide shade and serve as wind breaks

Strip cropping (the splitting of a farm in to section of 25 or more meters and then sowing different crops at the same time). This practice is highly common in the plans like the Mbaw Nso plain, Tikar plains, Mbokam and Ber plains; this is based on the fact that this area has enough land which is very accessible and scantily populated thus supporting this type of cropping system compared to the high and low plateau that are highly inaccessible and highly populated completely hindering the practice of this cropping system. 


\subsection{CONSERVATION AGRICULTURE CROP SELECTION AND CROPPING SYSTEM IN BUI}

\subsubsection{CROP SELECTION}

When land has been completely prepared using any of the preparation techniques above, sowing follow and it involves two stages that is;seed selection and then sowing (figure 5).

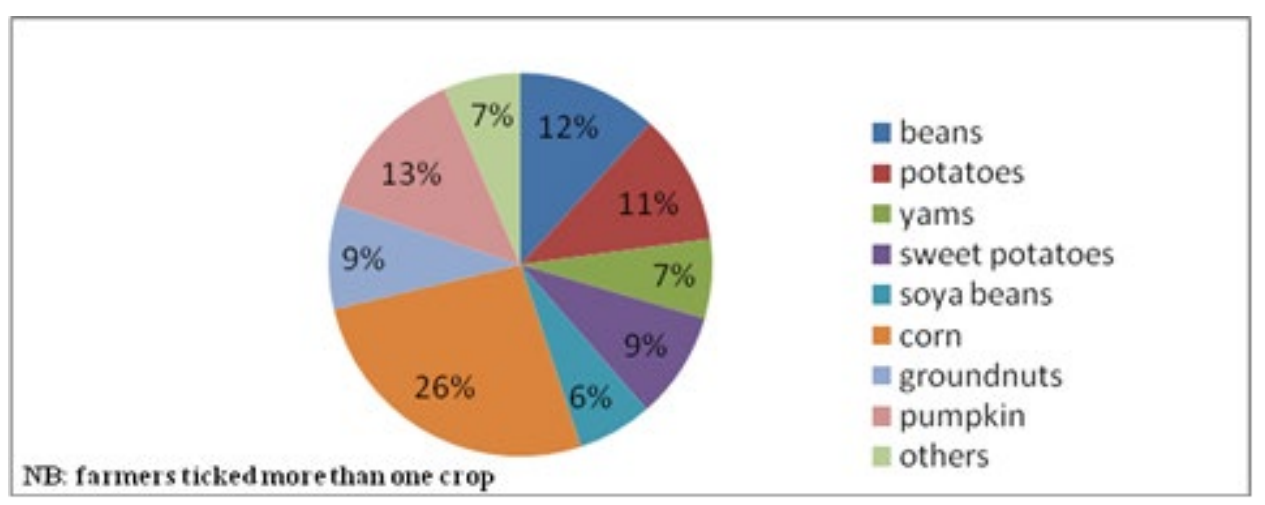

Figure 5: Common crops CA farmers cultivate in Bui

A series of crops are involved in the practice of CA in Bui Division these crops are mostly food crops and include maize (26\%), beans (12\%), soya beans (6\%), cocoyam (7\%),potatoes (11\%), sweet potatoes (9\%), groundnuts (9\%) and pumpkins (13\%) that are highly cultivated by the population of Bui (see figure 6 above) Some of these crops according to the farmers once planted the farmer in his/her life will never stress to look for seeds again; this is because they can coppice (grow back after they have harvested) and they include sweet potatoes,pumpkin, cocoyam and potatoes. For this reason, these crops have become very common in most farms in the Division. Others like maize, soya beans, potatoes and beans are highly cultivated for their potential to be rotated with one another.

\subsection{CROP MANAGEMENT}

Following general responds from the population, regular visit to the farm to take care of the crops and any problems that may arise is the order of the day for CA farmers in Bui division. The advantages here is that; "The farmer has time for other income-generating, social and community development activities".

\subsection{WEEDING}

This may involve hand, hoe or cutlass powered tools/equipment. The underlying principle is to avoid excessive disturbance of the soil and the crops while removing the weeds.

Mutua et al (2014) however says that this technique is time consuming especially in the initial stages of CA adoption when weed densities tend to be high. Some soil disturbance is evident and the method may be difficult in a CA system due to the presence of trash which the equipment would tend to drag along. This is true but in the context of Bui Division, it is different because these farmers are small-scale farmers that cultivate mainly for subsistence and lack the purchasing power to buy CA weeding equipment like weed scraper andanimal drawn weeder.

Weeds have been shown to germinate less in CA in beans and maize systems (50-60\% less) because the soil is less disturbed and less grassy weed germinate than in tilled soils. There is also evidence of allelopathic properties of cereal residues in respect to inhibiting surface weed seed germination (Jung et al. 2004). Weeds will also be controlled when the cover crop is cut, rolled flat, or killed by herbicides.

Spraying is also another technique that is used to manage their farms.in this case, it is done with the use of selective herbicides like Round- up as well as pesticides to protect their crops from being destroyed by pest example of pesticides common to the CA farmers in Bui division include borchem mainly use in vegetables and their applicability as mentioned earlier, require some expertise and practice. 


\subsection{POST HARVEST MANAGEMENT}

Harvesting of the crop is done manually with the use of hands; and after harvest, they leave the crop residue like the stalk of maize, beans, soya beans, potatoes etc. on the spot to rotten. The "crop residue help to increase the fertility of the soil.After harvesting, the crops are keep under dry conditions in bands or cribs in the case of maize, groundnuts and others like beans, soya beans are tied around the rafters of the house. For crops like potatoes, they are spread on the floor.

\subsection{PROMOTION OF CA IN BUI DIVISION}

The promotion of CA in Bui division is still at its infantry state. Its development in Bui has been rendered by mainly three stakeholders; that is; the farmers, government and NGOs/CIGs (Table6).

Table 6: Organizations promoting CA in Bui Division

\begin{tabular}{|l|c|c|}
\hline Institution & Respondents & Percentage \\
\hline Farmers & 123 & 68,3 \\
\hline Government & 28 & 15,6 \\
\hline NGOs/CIGs & 17 & 9,4 \\
\hline Total & 168 & 93,3 \\
\hline Missing data & 12 & 6,7 \\
\hline Total & 180 & 100,0 \\
\hline
\end{tabular}

\subsection{FARMERS}

Like elsewhere in the world, CA promotion in Buihas developed to where it is by the initiative of the farmers; $68 \%$ of the population carries out this practice in Bui (table 6). This, is done through the use of indigenous knowledge (A cumulative body of knowledge, know-how, practices and representations maintained and developed by peoples with extended histories of interaction with the natural environment (UN report 2008)) that has been passed on from generation to generation. This knowledge is passed on through storytelling and by practice of parents who witness their parents do it.

CA in Bui Division is not a new practice it has existed for a very long time and is considered by the people as the only type of agriculture ever practiced by their forefathers.

According to a 95 years old $\mathrm{Pa}$, in Mbiame I quote "we no bi know we anything like cutlass and hoe the only thing where we be di useam for farm na govir 'a stick with a hurke' and then we burn nam or we plant".

This, therefore provide a vivid picture that CA in Bui Division is not a new practice but an old tradition that have just been modified with the use of modern tools like machetes, hoes, animal drawn weeder, weed scrapers and sprayers

\subsection{THE GOVERNMENT}

in line with the vision 2035 which state thus " Cameroon: an emerging, democratic and united country in diversity ". which synchronises the aspirations and hopes of various factors such as poverty reduction through employment and rural development, the Cameroon Government joined OHADA which is trying to promote community development through the development of cooperatives.

This strategy account only for $15 \%$ of CA promotion and has been very effective in Bui Division. This can be seen through the development of cooperatives that today stand out in the promotion of CA agriculture in Bui Division like the Mbaw Nso maize cooperative. That today stand as one of the maize producers of maize in northwest region through the use of tractors provided by the government to help promote CA in this area. These tractors are rented out by the cooperative to her members at very low cost who then cultivate maize in large quantities and the cooperative help to market it for them. 


\section{NGOs/CIGs}

These stakeholders in their part have been very lagging with only 9.6\% effort in the development of CA in Bui division. Although there are many that try to promote sustainable agriculture, they have mostly concentrated themselves in other sustainable practices like organic farming and agro forestry. Examples of such NGOs includeSHUMAS, BOMIFA, and RIBA agroforestry centre with little or no effort as far as CA is concern (MINADER 2016).

\subsection{SOCIO-ECONOMIC AND ENVIRONMENTAL BENEFITS OF CONSERVATION AGRICULTURE IN BUI}

The reality for many smallholder farmers in Bui division is that their soils have become severely depleted through conventional farming methods including ploughing, little or no replenishment of nutrients and burning of residues. Such practices have resulted, ultimately, in decreased yields. However, for those practicing CA, the story is different. Below are some of the advantages advanced by CA farmers in Bui division (table 7).

Table 7: Socio-economic and environmental benefits of CA

\begin{tabular}{|l|c|c|}
\hline Benefits & Respondents & Percentage \\
\hline less labour needed & 45 & 25,0 \\
\hline Improvement Livelihoods and self-esteem & 26 & 14,4 \\
\hline Increase in yields and drop input costs & 34 & 18,9 \\
\hline Stimulation of rural development and economies & 27 & 15,0 \\
\hline Reduce soil erosion and Increase soil fertility & 25 & 13,9 \\
\hline Protection of the environment & 11 & 6,1 \\
\hline Total & 168 & 93,3 \\
\hline Missing data & 12 & 6,7 \\
\hline Total & 180 & 100,0 \\
\hline
\end{tabular}

\subsection{SOCIO-ECONOMIC BENEFITS}

\subsubsection{LESS LABOR NEEDED}

CA eliminates power-intensive soil tillage, this is based on the fact that through the use of herbicides, tractors, and machetes for land preparation and planting, $25 \%$ of the population could attest to this. In the case of Bui, farm labor now remains within the circle of the family with the intense activities being spraying or clearing of the farm thus reducing the cost of hiring Labour. Table 8 below shows a comparison of time and labor difference between conventional agriculture and conservation agriculture.

Table 8: Labour requirement by different activities in conventional and conservation agriculture

\begin{tabular}{|l|c|c|c|c|}
\hline \multirow{2}{*}{ Activity } & \multicolumn{2}{|c|}{ Conventional agriculture } & \multicolumn{2}{c|}{ Conservation agriculture } \\
\cline { 2 - 5 } & methods & Labor required & methods & Labor required \\
\hline Land prep & slash, hip, burn, plough & 3 persons x days & slash, spread & 3 persons x 2-3 days \\
\hline Seeding & hand hoe & 4 persons x days & cutlass & 2 persons x 2 days \\
\hline Weeding & hand hoe & not mentioned but easier & Hand hoe & $\begin{array}{c}\text { not mentioned but } \\
\text { takes more time }\end{array}$ \\
\hline
\end{tabular}

Source: Shetto et al., 2007

\subsubsection{IMPROVEMENT LIVELIHOODS AND SELF-ESTEEM}

$14 \%$ of the population, also testified that food-secure family is well respected in a community when CA is adopted. CA helps to restore social dignity among households through the possibility of harvesting more than one 
food crop in a year. Income generated through the sale of surplus harvests is used to meet other household requirements, for example education, health services, purchasing small livestock and building houses.

CA gives farm families opportunities to improve their livelihoods. Farmers who have adopted CA no longer need to spend time tilling and now use that time in other ways, such as on-farm processing, doing petit businesses like retailing, which adds value to their production and also increase their family incomes.

\subsubsection{INCREASE IN YIELDS AND DROP INPUT COSTS}

CA has tremendous potential for achieving sustainable yield increases through improving the growth conditions for crops. This is achieved through the timely planting, thereby reducing the risk of the significant yield reductions associated with late planting, a common problem, particularly in smallholder farming systems when households delay planting as they wait to hire labor when practicing conventional farming.

Furthermore, the possibilities for farmers to prepare the land throughout the year because they do not need to wait for the rains as is the normal practice under conventional farming increases their yield. CA therefore enables farmers to plant on time. Among other benefits, timely planting enables crops to utilize the nitrogen flush that is available in the soil at the beginning of the season.

CA have also buffer farmers against the full impacts of dry spells during the crop growing season by prolonging the period in which water is available to crops. In drier regions like the Mbaw, mbokam and ber plains, improved water harvesting under CA also improves availability of moisture to crops.

Finally, the efficient utilization of agricultural inputs such as manure and inorganic fertilizers, which are precisely applied where the crop roots can readily access them through CA, has been considered by the farmers to be very efficient. This helps reduce amounts of inorganic fertilizers applied because the plant residues rotten and increase the fertility of the soil costs of production are lowered. Because of the above faacts, $18 \%$ of the population has turn to adopt conservation agriculture in their farms.

\subsection{STIMULATION OF RURAL DEVELOPMENT AND ECONOMIES}

Conservation agriculture has greatly stimulated rural development in Bui through the following channels an opinion that was accepted by $15 \%$ of the population:

- Reduced input requirements and costs under CA has resulted in better cash flows and savings. These have in turn resulted in increased spending, stimulation of markets and growth in the local economy of Bui; for example there has been a $10 \%$ increase in maize production in Bui division thanks to the adoption of CA in the plains of Bui (MINADER divisional delegation Bui 2016).

- Engagement by communities in other informal practices has increased thanks to the drop in the number of hours spent in the farm.

- Emergence of vibrant savings and credit cooperative organizations and investors like the Mbaw Nso maize cooperative society that has now partnered with foreign investors to produce and market maize.

\subsection{ENVIRONMENTAL BENEFITS}

\subsubsection{REDUCE SOIL EROSION AND INCREASE SOIL FERTILITY}

$13 \%$ of the population, propounded the fact that residues on the soil surface and cover crops like sweet potatoes and pumpkin reduce the splash-effect of the raindrops, and once the energy of the raindrops has dissipated the drops proceed to the soil without any harmful effect. This results in higher infiltration and reduced runoff, leading to less erosion. The residues and cover crops also form a physical barrier that reduces the speed of water and wind over the surface.

Through the residue from the crops and the nitrogen fixing cover crops like sweet potatoes, beans and groundnuts, the fertility of the soils in Bui division have been greatly improved this is based on the fact that this organic matter provides a conducive environment for the survival of microorganisms that help to facilitate the rapid decomposition of these residue making the soils fertile. Also, there is maximum utilization of the fertilizer that is 
Adoption of Conservation Agriculture and Analog Forestry in BUI Division, Northwest Region, Cameroon

applied since these organic matter from leafs help reduce runoff as explained above hence reducing the rapid loss of minerals through erosion.

\subsubsection{PROTECTION OF THE ENVIRONMENT}

Tillage accelerates decomposition of soil and soil surface organic matter into carbon dioxide. Reduced or zero tillage not only reduces this process, but reverses it. Besides acting as a sink for carbon dioxide and alleviating the problem of global warming, carbon sequestered by crop biomass increases soil organic matter - the primary energy source for soil fauna and microbes an idea that was shared by $6 \%$ of the inhabitants of Bui.

Groundcover promotes an increase in biological diversity below and aboveground; there are more beneficial insects where they are groungcover and mulch (Jaipal et al. 2002) and these help keep insect pests in check.

\subsubsection{CHALLENGES OF CONSERVATION AGRICULTURE IN BUI}

Despite the advantages of Conservation Agriculture as an innovation, its adoption by farmers, especially small scale farmers in Bui, has not been as anticipated. This is attributed to the following challenges advanced by the population;

\subsubsection{THE FEAR OF ADOPTING NEW INNOVATION}

Majority of the respondents had very low levels of education and mostly dominated by the old who are very adamant to change.Many are very use to ploughing and it has become the symbol of agriculture making it difficulty for them accepting that agriculture is possible without tillage.The fixed mind set of the farmers in their cultivation culture of ploughing has made it difficult for adoption of CA to the full.

\subsubsection{HIGH COST OF PRACTICING CONSERVATION AGRICULTURE}

The principal function of tillage is weed control and so, when tillage stops, weed control becomes a major factor. In many cases controlling the weeds present at seeding time has been achieved with herbicides, especially the widespectrum "glyphosate". Many of them indicated that it is very expensive adopting the technique since most of them don't have money to purchade the inputs and equipments like jab planters and even afford to hire a tractor for ploughing.

\subsubsection{KNOWLEDGE INTENSITY AND TIME}

Conservation agriculture is a knowledge intensive system and farmers, need to obtain, share and integrate new knowledge into their practices. But small-holder farmers are often poorly linked to knowledge and information systems, and even extensionpersonnel in many Bui have little access to new information.

The principles of conservation agriculture need to be adapted to local biophysical conditions and farmer circumstances. This takes time, and massive short-term uptake of CA is difficult - a problem for farmers looking for short-term benefits.

\subsubsection{RESIDUE AND BIOMASS MANAGEMENT}

Conservation farming promoters insist on crop residue retention and soil cover as key parts of conservation farming. Interviews carried out during this study showed that termite activity under conservation farming is generally said to increase with the presence of dry matter in the fields. However, some farmers' belief that burning crop residue improves the soil.

Also, when the great majority of conservation farming adopters seems to have stopped burning crop residue in recent years, soil cover may still be subject to neighbouring fires, unless other fire control measures have been put in place (which represent additional Labour). Indeed, retention of $30 \%$ of previous crop residue as recommended 
by conservation farming stakeholders is seldom achieved. This is mainly due to the fact that croplands become communalgrazing lands between harvest and the beginning of the next cropping season.During the dry season, crop residue (and other soil cover such as cover crops) arevirtually the only source of forage for livestock important in the Mbaw Nso plains.

\subsubsection{ANALOG FORESTRY IN THE CONTEXT OF BUI DIVISION}

$\mathrm{AF}$ in the context of Bui is defined as; "Analogue Forestry is a forest management system that seeks to restore degraded forest lands, often replacing inefficient slash and burn agriculture or cattle ranching, with highly productive and biologically diverse regenerated forests capable of meeting the extractive needs of local populations (e.g. firewood, fodder, fruits, nuts, subsistence crops, timber) while supplying them with a supplemental income and an ecologically stable environment" (CENEP 2008).

AF like CA has been greatly adopted in Bui division. CENDEP in 2008, reported about $60 \%$ of the population of Mbiame in Mbven sub division, kitiwum in kumbo central sub division, Wvem, sop and gomrin in Jakiri sub division are aware of AF (CENDEP newsletter 2008). From the fieldwork carried out, it was realized that; 61\% of the population of Bui acknowledge that analog forestry has been one of the agricultural practices that has been highly adopted in the area. From the field work carried out, it indicated that analog forestry is practiced either in individual farms, community forest/communal forest or water catchments (figure 6).
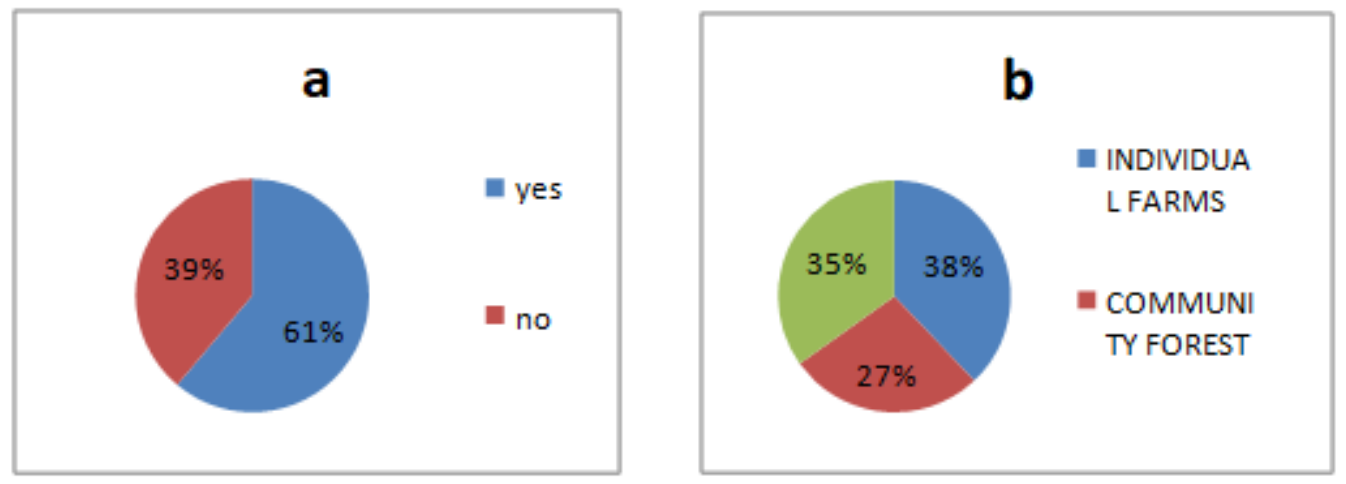

Figure 6: a) AF adoption by population; b) areas of AF adoption by population of Bui

\subsubsection{AGROFORESTRY IN INDIVIDUAL FARMS}

At the level of individuals, $\mathrm{AF}$ has been passedon from generation to generation; the irony remains that the population has been practicing analog forestry with no idea of what they have been doing.38\% of the development of this technology has been greatly promoted through this method. AF at the individual level is done locally without the consideration of AF principles and gap analysis to help in the development of physiognomic formulas to guide the designs. AF in Bui is dominated by two types of AF designs; that is; for auto consumption and for medicinal values.

\subsubsection{AUTO CONSUMPTION AF DESIGNS}

This design the most common of all and when anyone parades the streets and the suburbs of Bui division it can be easily witnessed. The design is compose of mainly fruit trees, crops and other natural species (table 9).

Table 9: Domestic trees and major cash/food crops in AF farms

\begin{tabular}{|l|l|}
\hline Tree category & Tree type \\
\hline Fruit trees & Mangoes, avocado, kolanuts guavas, plum, pawpaw, orange \\
\hline Cash/food crops & $\begin{array}{l}\text { Vegetables, plantains, Arabical, coffee, kolanuts, bananas, cowpeas, irish potatoes, beans, } \\
\text { groundnuts, cocoyams, garden eggs, cassava, }\end{array}$ \\
\hline Grass/herbs & $\begin{array}{l}\text { Elephant grass, hyperthermia, Guatemala, black jack, sporobolisis, gumifera, spear grass, } \\
\text { braken fern, mosses, lichens, twigs and epiphytic undergrowth. }\end{array}$ \\
\hline
\end{tabular}


Timber and hedge Eucalyptus,cypress, albizia, croton, polyscia pittosporium

trees

Timber and hedge trees are also introduced in farms to serve the purpose of soil improvement; fence, timber and fuel wood. These fruit trees are considered to be of great importance to the people as they serve as secondary sources of income. Others like cola nut trees are very common around big compounds (chiefdoms)signifying traditional identification and where sacrifices are carried out. As the saying goes," he who brings cola brings life"; cola is therefor considered a gift of peace to every Nso man.

These cola nut trees are usually accompanied by coffee plantations. Thecoffee grows very well in these conditions because the cola nut trees help to provide shade and their leafs greatly contribute in increasing soil fertility.

\subsubsection{MEDICINAL ANALOG FORESTRY DESIGN}

Some farmers in Bui have developed their analog forest to serve the purpose of providing them with medicine. Common species that can easily be identified in this area are shown in table 10.

Table 10: Analog forestry medicinal species in Bui

\begin{tabular}{|l|l|l|l|}
\hline N/S & Species & Part of the plant & Utility \\
\hline 1 & Prunus Africana & Bark & Treatment of cancer/malaria \\
\hline 2 & Canarium schwei & Seed/bark & $\begin{array}{l}\text { Local fruit that help to facilitate clotting of } \\
\text { wounds, bark is use to treat hypertension }\end{array}$ \\
\hline 3 & Vocanga sp & Leaves/roots & Use to treat wounds,boils and sores \\
\hline 4 & Croton macrost & seeds & Treat constipation and stomach cleansing \\
\hline 5 & Cola allata & seeds & Helps stimulate central nervous system \\
\hline 6 & Acasia mearnsi & bark & Use to stop internal bleeding \\
\hline 7 & Clausena anisata & roots & Chewed to combat indigestion \\
\hline 8 & Pitosporium viridi & Bark & Treat stomach pain, fever \\
\hline
\end{tabular}

Source: author 2016

In 2006, CENDEP made a rough estimate of 42 farmers in the communities of Oku and Vekovi. Who already had small plantations of Prunus Africana.These tree species are nurse in individual nurseries then transplanted in the farms during the months of August in mid rainy season and march in early rainy season so that they can grow and attain a height that can survive the dry season.

According to late pa Taleh of Mbiame, who own a medicinal AF, this (his) forest provided them him with every medicine he ever wanted and he believed that just by living and moving around his forest, the air he breath was already medicine since it came from his vegetation (CENDEP newsletter 2012) (see figure 5.10). This, therefore show how significant this practice has been to him and the community as a whole. To carry this design of AF, the practitioners have partition their farms in to sections; that is, one part for farming, grazing and the other for forest.

\subsubsection{ANALOG FORESTRY IN THE COMMUNITY/COMMUNAL FOREST AND CATCHMENTS}

This practice has been very common in all the seven main community forest in Bui and one of the communal forests (Mbiame communal forest) that is $27 \%$ of the $\mathrm{AF}$ has been adopted here and $35 \%$ in catchments some of which still appear to be the communal and community forest.It is initiated and implemented by CBOs (FMCs),CIGs and NGOs through projects. This is done through the implementation of projects in the forest by these organizations. the common AF techniques carried out by the communities involve the creating of nurseries and planting in the community and communal forest. This is done under the supervision of trained community facilitators. (figure 8). 

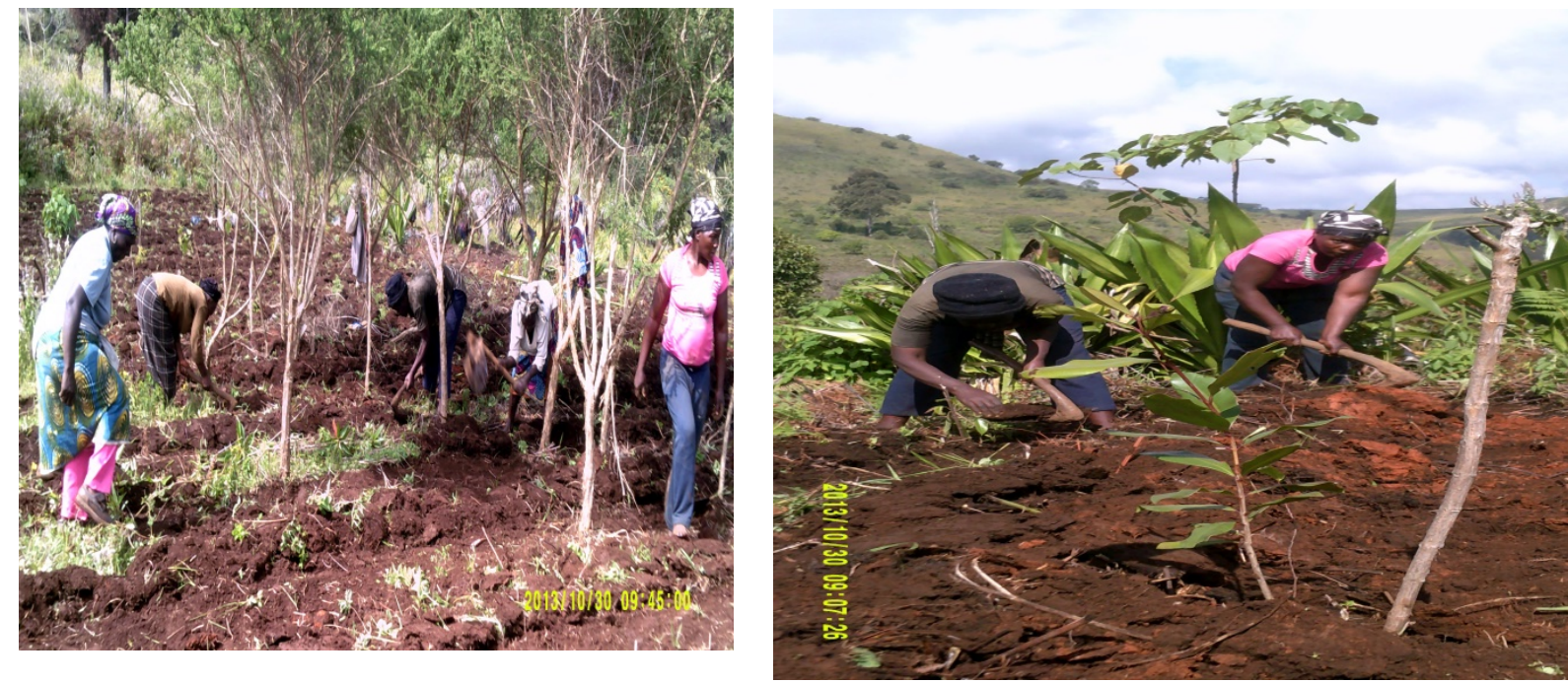

Figure 7: Bihkov women group of Mbiame growing trees and cultivating crops in communal forest Source: CENDEP achieves (2016)

In this situation, rather than using the old believe that completely discouraged people from cultivating around the community/communal forest and water catchment, this process encourages the cultivation around the forest and catchments under the condition that they plant trees then then they the farmers take care of it. This is based on the justification that when the trees grow, up to maturity, the farmers will abandone the site voluntarily without any one asking them .

AF has a lot in common with intercropping (the practice of planting two or more crops on the same plot) with both practices placing an emphasis on interaction between different plant species. Generally speaking, both $\mathrm{AF}$ and intercropping can result in higher overall yields and reduced operational costs.

\subsubsection{PROMOTION OF ANALOG FORESTRY IN BUI DIVISION}

$\mathrm{AF}$ is one of the sustainable agricultural practices that have been greatly promoted in Bui division; three stakeholders are involved in AF promotion farmers and NGOs and CIGs. They include, CENDEP. GREEN CARE, SHUMAS, RTC, NATURE CARE, Bihkov forest management committee vekovi, FMC Mbiame and the Bihkov women group Mbiame.

CENDEP is the pioneer organization that introduces the concept of AFand since 2008; they have introduce over four projects in Bui amongst which they include;

Restoration of degraded forest in Mbiame using analog forestry sponsored by IUCN NL for 3years.

This project had as objectives to;

- Sensitize the population of Mbiame, kitiwum, wvem and Gomrin on analog forestry.

- Develop community and individual nurseries.

- Plant 6000 tree seedlings in the Mbiame communal forest.

- Introduce the population in to NTFP activities

Restoration of degraded forest and rural agro- enterprise development using analog forestry for 18 months sponsored by GEF. The main objectives of the project included;(see figure 5.9 below).

- Empower women in forest restoration programs

- Plant over 8000 tree seedlings

- Provide a revolving fund for the livelihood sustenance

- Introduce activities that will ensure project continuity after 18 months like setting of beehives

- Training of participants on climate change, vegetable cultivation and organic manure production

The construction of the AF training centre in mbiame baptised 'Bihkov Training Centre'.After evicting farmers from the forest, the community in 2015 exceptionally allowed CENDEP to 'take residence' in the forest in order to

International Journal of Engineering Science Technologies 
continue to demonstrate Analog Forestry application in water and biodiversity conservation as well as livelihood enhancement for the local people. Thus, the Bihkov Training Centre focuses on assisting the local people to overcome poverty through the market as this lift more people out of poverty than aid ever will. Apart from training on analog forestry, it also offers training on the domestication of non-timber forest products such as wild vegetables, fruits and honey, multiplication and distribution of domesticated fruits and organic crop production.

The Centre is located on an 11 ha piece of land in the forest divided as follows:

- Infrastructure development: 3ha

- Production area (food crops): 1 ha

- Degraded forest land earmarked for restoration: 7ha

The Centre is being developed with a subsidy from Rich Forests and the International Analog Forestry Network (IAFN). Upon completion of the first phase of development it shall have capacity to host 16 people using shared accommodation facilities (2/room).

Since 2008 with the sensitization of local communities and the establishment of demonstration plots, which show the farmers how analog forestry works out in practice? A total of 21 sensitization meetings were organized, reaching 12,000 people in 7 villages in Bui.

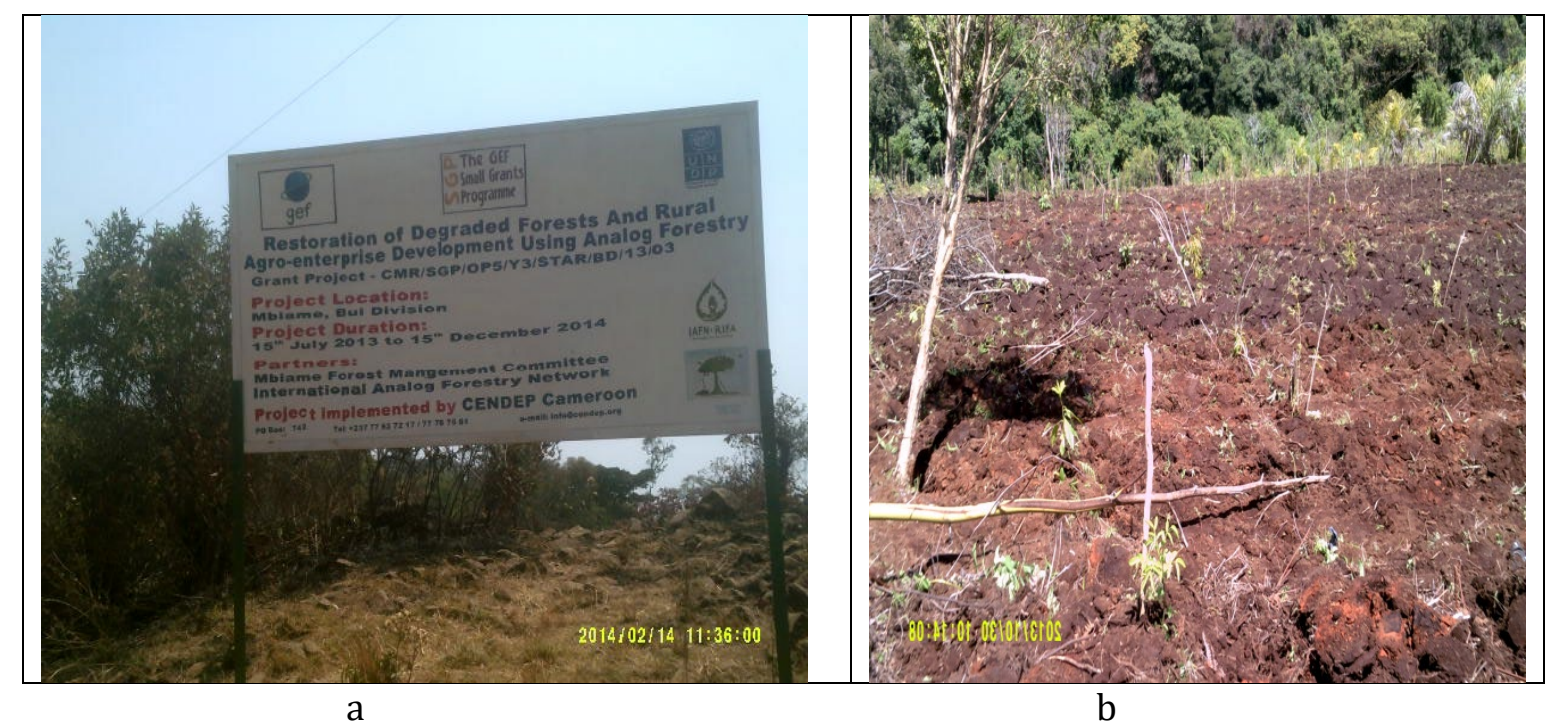

Figure 8: a) GEF/CENDEP sponsored project; b) cultivation of crops and growing of trees in the Mbiame communal forest. Source: CENDEP (2016)

Partner organizations like RTC, GREEN CARE, SHUMAS and NATURE CARE have also in their parts greatly contributed in the development of AF in Bui division.RTC alone has been promoting this practice in five communitiesalong the Ngongbaa forest area. Thatis; Wvem, Faa-kui, kai, Vekovi and Nkarkui,through the CBO call Bihkov community forest management group. They also have set up a demonstration AF that is strictly medicinal. Being a new concept in Bui, analogue forestry projects have three main objectives namely:

- To educate and raise awareness on the functions, products and services of traditional forests and the need for sustainable management to ensure that the forest benefits continue from generation to generation, through the practice of Analogue Forestry;

- To restore and/or expand degraded and man-made forest through enrichment planting, sustainable forest management and strengthening of local forest and water management institutions;

- To improve livelihoods of the local population by diversifying farm and forest based income generating sources through the promotion of analogue forestry, sustainable agriculture such as organic farming, bee keeping and improved pasture management, cultivation of agricultural and forest-based products having economic potentials. 


\subsubsection{BENEFITS OF AGROFRESTRY IN BUI DIVISION}

\begin{tabular}{|l|c|c|}
\hline Benefits of AF & Respondents & Percentage \\
\hline increases income & 40 & 22,2 \\
\hline Promote indigenous knowledge & 15 & 8,3 \\
\hline promote social group interaction and development & 28 & 15,6 \\
\hline restoration of ecosystem services & 32 & 17,8 \\
\hline increases protection of Forest & 38 & 21,1 \\
\hline create beautiful environment & 15 & 8,3 \\
\hline Total & 168 & 93,3 \\
\hline Missing data & 12 & 6,7 \\
\hline Total & 180 & 100,0 \\
\hline
\end{tabular}

\section{SOCIO-ECONOMIC BENEFITS}

\subsection{INCREASE IN INCOME}

The cultivation of crops and introduction of trees in farms has really been viewed as agreat source of income by the AF farmers in Bui. For those who have practice the technique since its introduction in 2008. It has really been beneficial; $22.2 \%$ of the farmers confirm that apart from getting only from saling of their crops as was the case before, today they are able to increase their incomes from the sale of NTFPs like honey, Prunus barks, fruits like oranges, guavas, pear and tree seedlings that are bought by organizations during project periods.One farmer increased his yearly income from 400000 to 600000 FCFA in just 4 years. He said he achieved these results without chemical fertilizers, herbicides, pesticides or heavy machinery, but by creating compost, plant nurseries and combinations and successions of species.

Analog forestry intensifies agriculture in an ecologically sound way.as a result of this, the farmers now boost of drop in farm expenses as they are able to grow healthier crops with no application of fertilizers thanks to the fertile soils resulting from the decomposition of tree leafs and compost produce using analog techniques gotten through trainings.

\subsection{PROMOTE INDIGENOUS KNOWLEDGE}

Analog forestry involves blending traditional knowledge and science. It recovers and valorizes indigenous knowledge, creating systems that are familiar to traditional societies and meet the needs of contemporary forestdependent communities. This has been the case in Bui Division, in the sense that $8,3 \%$ of the people believe that through the encouragement by AF promoting organizations in Bui, they have emprise it because it supports them revisit the old lifestyle of their forefathers of living the forest because of its value by introducing it in their farms through AF. Also, it hepls to protect some tree and animal species that appear to be endangered like the mannermann in the Kilum mountain Forest a specie of birds that are endangered.

\subsection{PROMOTE SOCIAL GROUP DEVELOPMENT AND INTERACTION}

$\mathrm{AF}$ is a complex technique that requires the participation of many people before its package of benefits can be explore to its fullest. $15.6 \%$ of the farmers indicate the enthusiasm encourage by AF development in Bui division.In all the six divisions in Bui division, there exist forest management committees that have been developed as a result of the AF. Examples include; the Bihkov women group and FMC Mbiame, the FMC Dom, the Faa-kui water management committee (FWMC).

These groups, although developed for the soul purpose of forest restoration and management, have gone beyond that, today; these groups now contribute to the livelihood improvement of her members through savings by members and revolving funds from projects that are loan out to farmers at very low interest rates. 


\subsection{ENVIRONMENTAL BENEFITS}

\subsubsection{RESTORATION OF ECOSYSTEM SERVICES (INCREASE WATER SUPPLY)}

Reforesting according to the analog method results in Bui has resulted in the restoration of ecosystem services such as the supply of water. 200 to 250 farmers in and around Kitiwum village in Bui have been practicing analog forestry since 2008 an idea which $17.8 \%$ of the population attest has been very profitable to them.

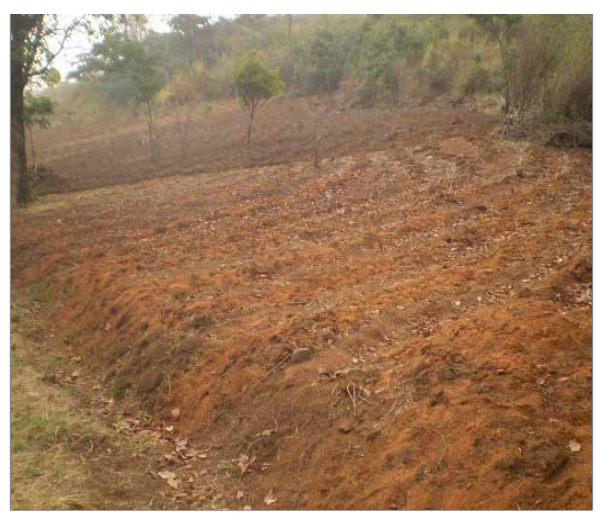

a

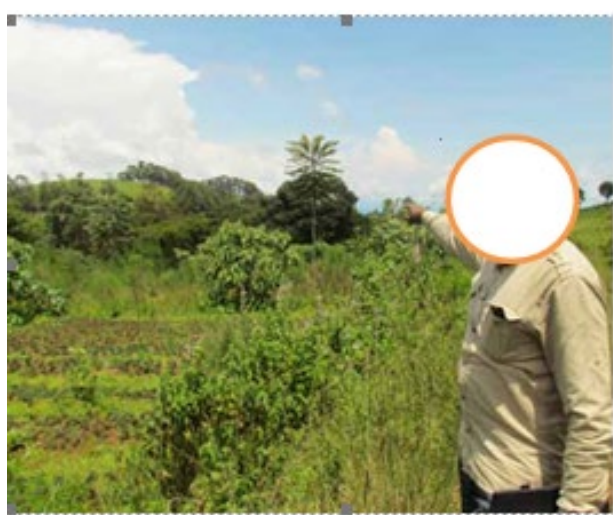

b

Figure 9: Agroforestry techniques used to restored section of the Mbiame communal forest a) area in 2006/ b) area restored in 2016

Source: CENDEP (2016)

They already enjoy a better lifestyle. The regreening of the land has resulted in more abundant water in the dry season. Farmers have their own water sources and do not share the same water collection points with cattle as in the past. In the dry season they do not have to take water from only one, perhaps contaminated spot. The degree of water related diseases such as cholera, diarrhea and typhoid has gone down in the area. Ten communities are practicing analog forestry and 200,000 to 300,000 people in the region benefit from an increased supply of water

\subsubsection{INCREASE PROTECTION OF COMMUNITY /COMMUNAL FOREST}

Through the many AF restoration projects that have been introduce in the various community /communal forest, forest protection have increase an opinion shared by $21.1 \%$ of the population. This has been possible through the creation of Management committees that have gone a long way to appoint forest monitors. These monitors have as responsibility to visit the forest regularly, catch and hand culprits who break the rules governing the forest like; no cutting down of trees, no hunting (figure $10 \mathrm{a}$ ).

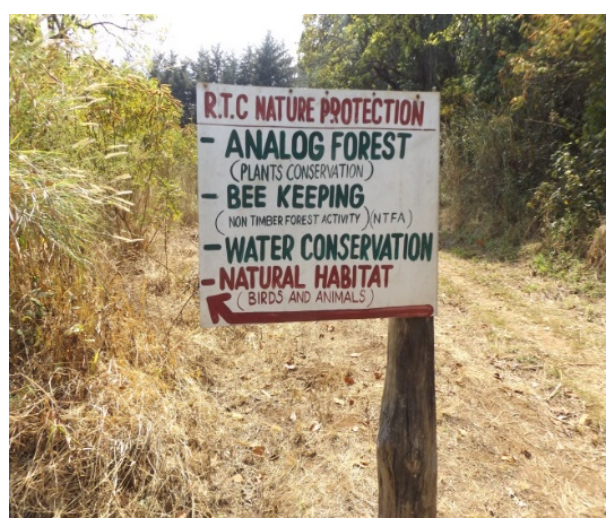

a

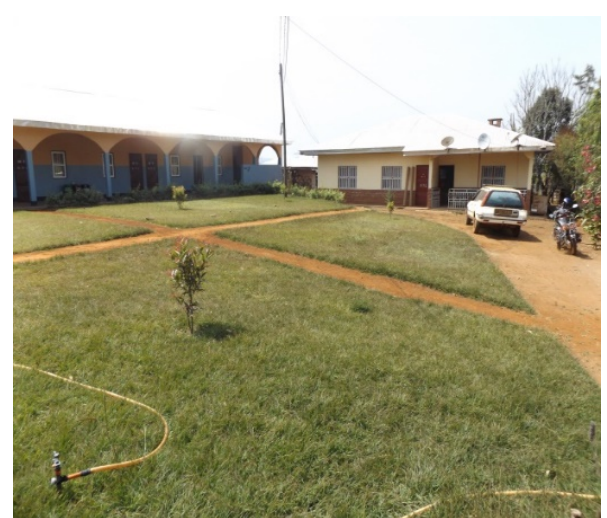

b

Figure 11: AF environmental protection and use for center design a) RTC nature protection using AF b) beautiful RTC design using AF 
Also, these organizations organize regular fire tracing that have also help to reduce rampant fires during the dry season that always cause serious damage to the forest and their crops.

\subsubsection{CREATE AN AESTHETIC ENVIRONMENT}

Finally, $8.3 \%$ of the population agreed that promoters of AF in Bui Division, like the RTC boost that AF produces very beautiful environments than any other forestry practice. This is based on the fact that this process has a series of principles that guide its design. The practice, even gives you room to add and substrate species which the design donot deem necessary in his farm and through this advantage, if the forest finammy grow to maturity, it creates a very beautiful environment. (figure11b showing the RTC design using AF techniques).

\subsubsection{CHALLENGES OF ANALOG FORESTRY IN BUI}

A series of problems where indicated to plague the full adoption of AF in Bui Division. These challenges, affect both the individual farmers and NGIs/CIGS. The challenges include;

\subsubsection{BUSH FIRES}

Rampant push fires, where indicated as one of the problem causing the destruction of forest in Bui. These believe to be cause by frequent fire between FMC members and grazers who stubbornly set fire in the forest and peoples farms in other to regrow weed for their cattle. These fires, cause serious damage to trees planted by the farmers of FMC and to the beehives that also help as a source of income to the people.

\subsubsection{LONG DURATION AND MANY STEPS INVOLVED}

To benefit from $\mathrm{AF}$, it takes a very long time so farmers find it difficult to exercise that patience before start benefiting from AF in Bui hence making it application very difficult. Furthermore, AF is very complex and involves many steps that also require more time to follow up something the people find it difficult doing

\subsubsection{NEEDS VAST LAND}

For AF to be implemented to its fullest, it require a vast land something which is a great luxury to the people of Bui. The area is very highly and farmers only have small parcels of land in the lowlands and to take this land and split in to two or incorporate tress in them, the farmers find it very difficult; in essence making AF adopting difficult.

\subsubsection{FARMER/GRAZER CONFLICT}

Frequent conflicts between farmers and grazers is a very common problem that is highly witness in Bui division. These conflicts arise as a result of the unsustainable grazing practices adopted by the grazers; that is since they do not have paddocks where cattle can graze at night, they turn to send their cattle in to peoples farms at night to graze on the crops then remove then by morning. This practice, have affected both NGOs and farmers in this communities and have greatly hinder AF development in the area.

\section{CONCLUSION}

It was revealed that $81 \%$ of the population of Bui have adopted CA and $61 \%$ have adopted $\mathrm{AF}$. For CA it has been adopted in their various farms and in the course of adoption, five CA strategies are used. Although CA have greatly been adopted in Bui it faces the following challenges like the mind-set of the plough, Weed control, Residue and biomass management, Knowledge intensity and time.to develop the technique, three stakeholders have taken the initiative to develop it that is; $68.3 \%$ of the technique by farmers, $15.6 \%$ by the government and $9.4 \%$ by NGOs/CIGs. 
$\mathrm{AF}$ adoption have been in three different areas in Bui by the communities; that is in their farms (38\%), community forest (27\%), and in water catchments (35\%). Two types of AFs are grown in Bui;the auto consumption and medicinal analog forest. AF is plague with many challenges like bush fires, long duration and many steps involved, farmer/grazer conflict, needs vast land. The strategy is $100 \%$ promoted by NGOs/CIGs like CENDEP, GREEN CARE, NATURE CARE, RTC and SHUMAS through projects with international organizations like IAFN and Rich Forest.

The research also revealed that CA and AF have been socially, economically and environmentally. For CA, the following benefits have been identified in Bui;less Labour needed which $25 \%$ confirm was one of the greatest benefits CA grant to the population of Bui, Improve livelihoods and self-esteem confirm by $14.4 \%$ of the people, Increase in yields and drop input costs was also confirm by $18.9 \%$ of the population, Stimulation of rural development and economies by $15.0 \%$ of the people, Reduce soil erosion and Increase soil fertility by $13.9 \%$ of the farmers and finally, Protection of the environment which was confirmed by $6,1 \%$ of the farmers. In total, these benefits contribute to $93.3 \%$ of the livelihood of the people of Bui.

It also revealed that AF has been very beneficial in the communities. Some of these benefits of AF in Bui include; increase income confirm by $22.2 \%$ of the farmers as one of the greatest benefits, promote indigenous knowledge indicated by $8.3 \%$ of the farmers as one of the benefits, promote social group interaction and development agreed by $15.6 \%$ of the population, restoration of ecosystem services which appear to have $17.8 \%$ of the importance, increases protection of forest was also one of the environmental benefits that $21.1 \%$ of the population accepted that this was one of the environmental benefits and finally create beautiful environment was also indicated by $8,3 \%$ of the farmers as one of the environmental benefits.

\section{SOURCES OF FUNDING}

None.

\section{CONFLICT OF INTEREST}

None.

\section{ACKNOWLEDGMENT}

None.

\section{REFERENCES}

[1] Appraisal Report Grassfield Decentralised and Participatory Rural Development Project. Department of Agriculture and Rural Development West and Central Region OCAR, April 2003.

[2] Blank, D. 2008.A fresh look at life below the surface.In: Goddard, T., Zoebisch, M,

[3] Gan, Y., Ellis, W., Watson, A. and Sombatpanit, S. (eds): No-till farming

[4] systems. Bangkok. World Association of Soil and. pp73-81.

[5] Dickinson, A. K. (2014). Analog Forestry: Creating Productive Landscapes. ETFRN News 56: November 2014. International Analog Forestry Network, San Jose, Costa Rica.

[6] Dufty, A.C. (1998) Analogue Forestry. In Stelling, F. (ed.) From little things, big things grow ... Revegetation guide for the South West Slopes. Department of Land and Water Conservation, New South Wales.

[7] Dumanski, J., R. Peiretti, J. Benetis, D. McGarry, and C. Pieri (2006). The Paradigm of Conservation Tillage. Proceedings of World Association of Soil and Water Conservation Paper No. P1-7, 58-64.

[8] DFID (1999). DFID and the International Development Target. National Strategies for Sustainable Development, Key Sheets, Issue No. 1, Department for International Development, London.

[9] Foahom, B. (2001). Biodiversity Planning Support Programme Integrating Biodiversity into the Forestry Sector. Paper presented for an International Workshop on "Integration of Biodiversity in National Forestry Planning Programme”. CIFOR Headquarters, Bognor, Indonesia, 13-16 August 2001. 
TSI Evaristus Angwafo, and Kemkia Christian Danernyuy

[10] FAO (2006). Agriculture and Consumer Protection Department, Rome: FAO <http://www.fao.org/ag/magazine/0110sp.htm> (accessed 4 March 2015).

[11] FAO (n.d.). Conservation Agriculture, Agriculture and Consumer Protection Department, Rome: FAO <http://www.fao.org/ag/ca/> (accessed 4 March 2015)

[12] Friedrich, T. 2005. Why should the world be concerned about sustainable resource

[13] management in agriculture? III World Congress on Conservation Agriculture,

[14] Nairobi, October3-7.7p.

[15] Hauswirth D., Pham T.S., Nicetic O., Tivet F., Le Quoc D., Van de Fliert E., Kirchhof, G., Boulakia S., Chabierski S., Husson O., Chabanne A., Boyer J., Autfray P., Lienhard P., Legoupil J.-C., Stevens M. L. (eds) (2012). Conservation Agriculture and Sustainable Upland Livelihoods. Innovations for, with and by Farmers to Adapt to Local and Global Changes -Proceedings of the $3^{\text {rd }}$ International Conference on Conservation Agriculture in Southeast Asia.Held in Hanoi, Vietnam, 10th-15th December 2012.CIRAD, Montpellier, France; NOMAFSI, PhuTho, Viet Nam; University of Queensland, Brisbane, Australia.372 p.

[16] Hobbs, P.R., Gupta, R., and Sayre, K. (2008). "The Role of Conservation Agriculture in Sustainable Agriculture", Philosophical Transactions of The Royal Society, Biological Sciences, vol. 363, pp. 543-555.

[17] IIRR and ACT (2005). Conservation Agriculture: A Manual for Farmers and Extension Workers in Africa. International Institute of Rural Reconstruction, Nairobi; African Conservation Tillage Network, Harare. ISBN 9966-9705-9-2

[18] Jodha, N.S. (1990). "Rural Common Property Resources - Contributions and Crisis". Economics and Political Weekly, June 20, A65-A78.

[19] Lambi, C.M. (2001). "Revisiting the Environmental Trilogy: Man, Environment and Resources”. In Lambi, C.M. (Ed): Environmental Issues: Problems and Prospects. Unique Printers, Bamenda. PP. 105 - 117.

[20] Lambi, C.M. (2001). (Ed). Environmental Issues: Problems and Prospects. Unique Printers, Bamenda.

[21] Mitchell, B. (1979). Geography and Resource Analysis. Second Edition. Longman Scientific and Technical Group.UK.

[22] Maggs, P and Hoddinott, J. (1997). The Impact of changes in common property resource management on intrahousehold allocation. Food Consumption and Nutrition Division (FCND) Discussion Paper No. 34. International Food Policy Research Institute. WashingtonDC. USA.

[23] Neelam C., 2Y.S. Saharawat and 3V. Sivaram (2013): Conservation Agriculture: An Option to Enhance Pollinators and Sustainability. World Journal of Agricultural Sciences 9; IDOSI Publications.

[24] Njilla, R.M.N. (2010). Management of common property resources for sustainable rural livelihoods in bui division, north west region of Cameroon. Post graduate dissertation, Department of Geography.

[25] Nyende, Paul; Nyakuni, Anthony; Opio, John Peter; Odogola, Wilfred.2007. Conservation

[26] Agriculture : a Uganda case study. Nairobi. African Conservation Tillage Network, Centre de Coopération Internationale de Recherche Agronomique pour le Développement, Foodand Agriculture Organization of the United Nations

[27] Njilla, R.M.N. (2000). Land Use Effects on Surface Water Systems in Kumbo Central Sub Division, North West Province. Undergraduate dissertation, Department of Geography.

[28] Ndenecho, E.N. (2005). Biological Resource Exploitation in Cameroon. From Crisis to Sustainable Management. Unique Printers, Bamenda.

[29] Ndenecho, E.N. (2007).Upstream Water Resource Management Strategy and Stakeholder Participation. AGWECAM Printers, Bamenda.

[30] Neba, A. (1999). Modern Geography of the Republic of Cameroon, 3rd edition. Neba Publishers, Bamenda, Cameroon.

[31] Naudin k., Husson o., Rollin d., Guibert h., Charpentier h., Abouabba a, Njoya a.,Olinaj.p., Seguy l. (n.d):Conservation agriculture adapted to specific conditions -No tillage for smallholder farmers insemi-arid areas (Cameroon and Madagascar).

[32] Sims. B, Friedrich. T, Amir K, Kienzle J.(2009):Agroforestry and Conservation

Agriculture: Complementary practices for sustainable development ;II World Congress of Agroforestry, Nairobi, Kenya

[33] Sebastian, K., Fischer, G. and Nachtergaele, F. (n.d.)."Appropriate Agroecological Zones: Tropical Warm Subhumid, Tropical Warm, Semi-Arid Agro-Ecological Zones in SSA", Harvest Choice/IFPRI<http://droppr.org/data/map/aez09ssa> (accessed 4 March 2015). 
[34] Senanayake, R. \& Jack, J. (1998). Analogue Forestry: An Introduction. Monash Publications in Geography No. 49. Melbourne: Monash Print Services.

[35] Uthes et al n.d: Conservation Agriculture in AFRICA: Analysing and Foreseeing its Impact - Comprehending its Adoption: CA2Africa.

[36] Wetten hall, G. and Penna, I. (2013). Analogue Forestry in Practice in Sri Lanka. Australian Forest Grower. Summer 2013.5. 